\title{
Pelatihan Keterampilan Dasar Komputer Dan Teknologi Informasi Bagi Siswa Sekolah Dasar Di Sd Negeri 2 Tibubeneng
}

\author{
Nengah Widya Utami, Ni Luh Putu Ning Septyarini Putri Astawa \\ Sekolah Tinggi Manajemen Informatika dan Komputer (STMIK) Primakara \\ e-mail: widya@primakara.ac.id
}

\begin{abstract}
Abstrak
Hasil analisis situasi menunjukkan minimnya kondisi pendidikan yang berkaitan dengan Teknologi Informasi dan Komunikasi (TIK) khususnya bagi siswa-siswi di sekolah dasar. Tujuan kegiatan ini adalah untuk memberikan pengetahuan dan keterampilan dasar komputer serta teknologi informasi kepada siswa di sekolah dasar. Pelatihan ini diharapkan memberikan bekal kepada siswa tentang keterampilan dasar komputer dan teknologi informasi khususnya internet bagi pengembangan ilmu pengetahuan, serta sebagai bentuk pengembangan nilai-nilai karakter dalam bidang pendidikan berupa rasa keingintahuan, kreatif, inovatif, dan komunikatif. Subjek kegiatan pengabdian kepada masyarakat adalah siswa-siswi di SD Negeri 2 Tibubeneng, Kabupaten Badung yang berjumlah 104 orang. Kegiatan pelatihan ditunjang dengan metode ceramah, tanya jawab, demonstrasi, dan praktek langsung penggunaan aplikasi komputer. Hasil kegiatan menunjukkan bahwa pelatihan ini dapat memberikan pengetahuan, pemahaman, dan keterampilan bagi siswasiswi dalam menggunakan aplikasi dasar seperti Paint dan Microsoft Word, serta memahami penggunaan internet sehat dalam pencarian informasi.
\end{abstract}

Kata kunci: pelatihan, keterampilan, komputer, tibubeneng.

\begin{abstract}
The results of the situation analysis indicate the lack of educational conditions related to Information and Communication Technology (ICT), especially for students in primary schools. The purpose of this program is to provide knowledge and basic skills of computers and information technology to students in elementary schools. The training is expected to provide students with basic skills in computers and information technology, especially the internet for the development of science, and as a form of character values development in the field of education in the form of curiosity, creative, innovative, and communicative. The subject of this program is students in SD Negeri 2 Tibubeneng, Badung Regency, totaling 104 students. Training activities are supported by lecture, question and answer, demonstration, and direct practice methods for using computer applications. The

http://ejournal.urindo.ac.id/index.php/PAMAS
\end{abstract}

Article History :

Submitted 21 April 2020, Accepted 26 April 2020, Published 29 April 2020 
results of the activities show that this training can provide knowledge, understanding and skills for students in using basic applications such as Paint and Microsoft Word, as well as understanding internet health usage in information retrieval.

Keywords: training, skills, computer, tibubeneng.

\section{PENDAHULUAN}

Tibubeneng merupakan sebuah desa/kelurahan yang terletak dalam (daerah) kecamatan Kuta Utara, Kabupaten Badung, Wilayah Bali. Penduduk desa Tibubeneng terdiri dari 5.286 laki-laki dan 5.206 perempuan dengan sex rasio 101. (Wikipedia, 2015). Secara geografis batas desa Tibubeneng yaitu sebelah utara yaitu desa Dalung, kecamatan Kuta Utara, di sebelah selatan yaitu samudra Indonesia, di sebelah timur yaitu Kelurahan Kerobokan, Kuta Utara, dan di sebelah barat yaitu desa desa Canggu, Kecamatan Kuta Utara (Pemerintah Kab. Badung, 2015).

Teknologi informasi dan Komunikasi (TIK) memiliki perkembangan yang sangat pesat dan meliputi berbagai bidang. Bidang pendidikan merupakan salah satu bidang yang dipengaruhi oleh teknologi informasi. Tuntutan global menuntut dunia pendidikan untuk selalu dan senantiasa menyesuaikan perkembangan teknologi terhadap usaha dalam peningkatan mutu pendidikan, terutama penyesuaian penggunaannya bagi dunia pendidikan khususnya dalam proses pembelajaran (Budiman, 2017). Proses pembelajaran yang dapat mengembangkan hal tersebut salah satunya melalui pembelajaran yang mengoptimalkan media komputer (Hayati, dkk, 2018).

Pemerintah telah menjadikan TIK menjadi mata pelajaran peminatan pada tingkat sekolah dasar dan sekolah menengah. Bekal kemampuan menggunakan dan memanfaatkan perangkat teknologi informasi dan komunikasi merupakan salah satu faktor kunci untuk mengejar ketertinggalan SDM Indonesia dari bangsa-bangsa lain. Jalur pendidikan formal berpotensi dan bernilai strategis untuk menyelenggarakan pendidikan dan latihan di bidang TIK yang idealnya dimulai sejak dini. Hal ini mengisyaratkan pentingnya bagi anak-anak sejak dini disediakan pengalaman dalam memanfaatkan sarana 
TIK khususnya komputer. Pembelajaran TIK sejak dini juga bermanfaat untuk menambah hardskill dan softskill sehingga dapat berkontribusi dalam meningkatkan kualitas, daya saing, daya guna dan kemandirian untuk pendidikan para siswa (Rokhman, dkk, 2018).

Namun pada kenyataannya, program pendidikan TIK belum bisa menjangkau siswasiswa di beberapa sekolah yang terletak di pedesaan, termasuk juga sekalah dasar yang berada di SD Negeri 2 Tibubeneng. Hal ini disebabkan karena tidak adanya guru yang mampu mengajarkan materi tersebut dan kurangnya fasilitas yang mendukung.

\section{METODE}

Kegiatan ini terdiri dari empat tahap yaitu: (1) tahap perencanaan, (2) tahap pelaksanaan, (3) pendampingan dan (4) tahap evaluasi. Tahap perencanaan telah ditetapkan hal-hal sebagai berikut: tempat/lokasi kegiatan dipilih di SD Negeri 2 Tibubeneng, yang terletak di Jalan Pantai Berawa No. 126, Tibubeneng, Kec. Kuta Utara, Kabupaten Badung.

Tahap pelaksanaan berupa (1) penyajian materi secara teori (2) dilanjutkan dengan praktikum menggunakan aplikasi paint, microsoft word, dan internet, serta (3) tahap pendampingan dan evaluasi. Pelatihan ini melibatkan dosen program studi Sistem Informasi dan mahasiswa STMIK Primakara dengan bekerja sama dengan SD Negeri 2 Tibubeneng yang melibatkan siswa-siswi kelas 4, 5, dan 6 sebagai subyek sasaran dengan jumlah siswa sebanyak 104 orang.

Kegiatan ini menggunakan metode dalam bentuk pelatihan keterampilan melalui ceramah, demonstrasi, tanya jawab, dan praktikum. Adapun tahapan-tahapan dalam pelaksanaan kegiatannya:

a) Ceramah digunakan untuk menyampaikan pengetahuan secara umum tentang pemanfaatan aplikasi keterampilan dasar komputer dan internet.

b) Demontrasi digunakan untuk memberikan keterampilan langsung mengenai proses menggambar dan mewarnai menggunakan aplikasi Paint, membuat dokumen dengan

http://ejournal.urindo.ac.id/index.php/PAMAS 
Jurnal Pelayanan dan Pengabdian Masyarakat (PAMAS)

Microsoft Word, dan mencari informasi yang bermanfaat dan terpercaya melalui internet

c) Tanya jawab digunakan untuk melengkapi hal-hal yang belum terakomodasi oleh kedua metode di atas.

d) Praktikum menggambar dan mewarnai objek menggunakan aplikasi paint, membuat dokumen menggunakan Microsoft Word, dan mencari informasi di internet yang ditujukan kepada siswa dengan melibatkan seluruh peserta pelatihan.

e) Evaluasi dilakukan dengan cara pengamatan langsung melalui penilaian kinerja dan hasil karya peserta.

\section{HASIL DAN PEMBAHASAN}

Kegiatan pengabdian ini mendapat respon yang positif dari para pimpinan, guru, dan siswa-siswi SD Negeri 2 Tibubeneng, dimana seluruh peserta sangat antusias mengikuti kegiatan dan para guru bersedia dengan senang hati membantu dalam proses awal sampai akhir kegiatan. Kepala Sekolah SD Negeri 2 Tibubeneng, Ibu Ni Nengah Sukerti mengapresiasi kegiatan pengabdian yang dilaksanakan, dan memberikan saran agar pelatihan dapat dilaksanakan secara berkesinambungan dengan ilmu-ilmu Teknologi Informasi dan Komunikasi lainnya, dimana kegiatan tidak hanya ditujukan kepada siswa melainkan guru serta pegawai di SD Negeri 2 Tibubeneng.

Kegiatan ini dilaksanakan selama 1 hari pada tanggal 31 Oktober 2019 di ruang Aula SD Negeri 2 Tibubeneng. Tahapan pencapaian target hasil diuraikan menurut runtutan metode pelaksanaan dengan beberapa modifikasi sesuai kondisi lapangan, dan selanjutnya secara detail diuraikan berikut :

1) Tahap Perencanaan

Perencanaan dilakukan dengan melakukan diskusi bersama pihak SD Negeri 2 Tibubeneng dan persiapan alat/bahan untuk pelaksanaan kegiatan pada tanggal 28 Oktober 2019.

http://ejournal.urindo.ac.id/index.php/PAMAS 


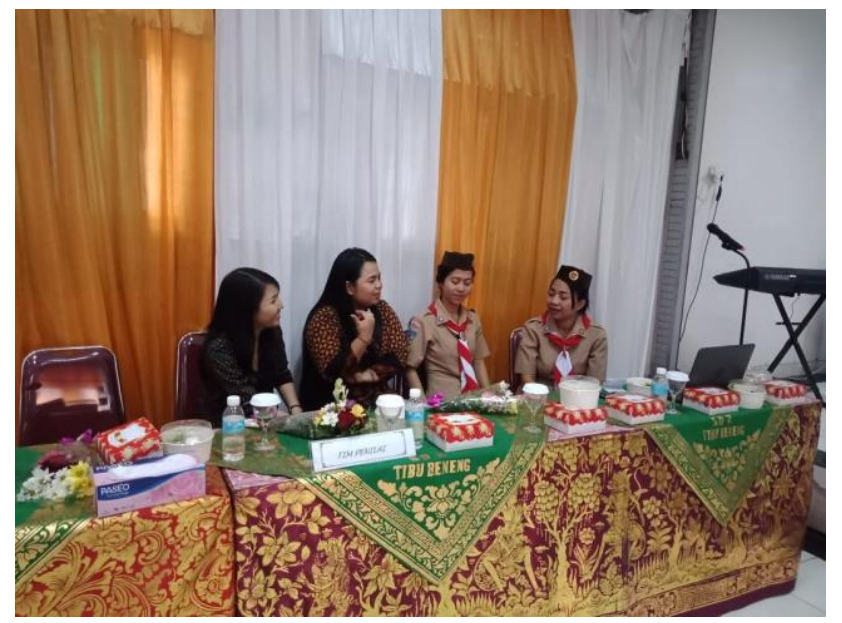

Gambar 1. Diskusi Rencana Pelaksanaan kegiatan dengan Guru

\section{2) Tahap Pelaksanaan}

Tahapan Pelaksanaan program dengan melaksanakan pelatihan dasar komputer dan teknologi informasi, yang meliputi kegiatan pembukaan, pengenalan aplikasi komputer dan internet sehat, pelatihan mengambar dan mewarnai dengan aplikasi Paint serta pelatihan Microsoft Word.

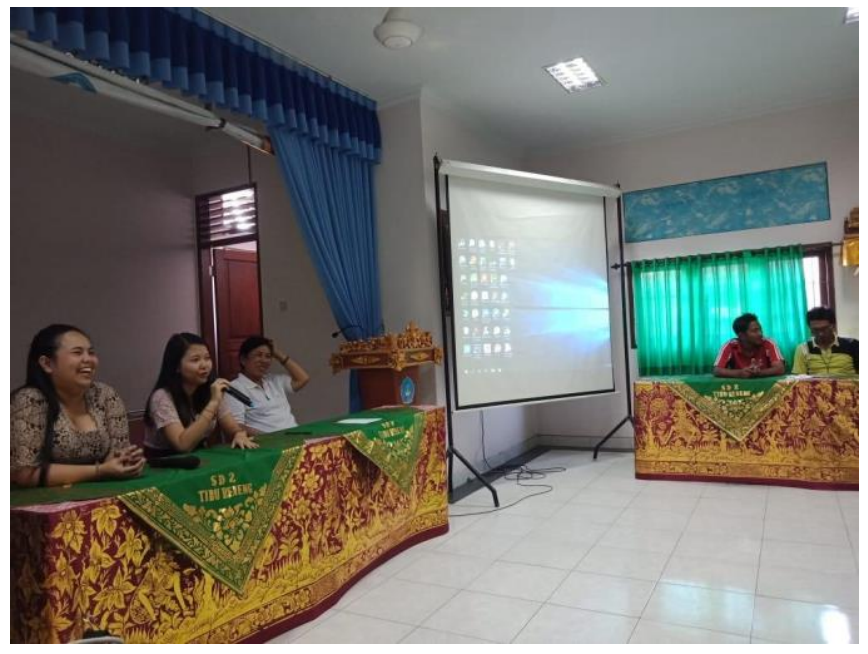

Gambar 2. Pembukaan oleh Kepala Sekolah dan Pelaksana Kegiatan 


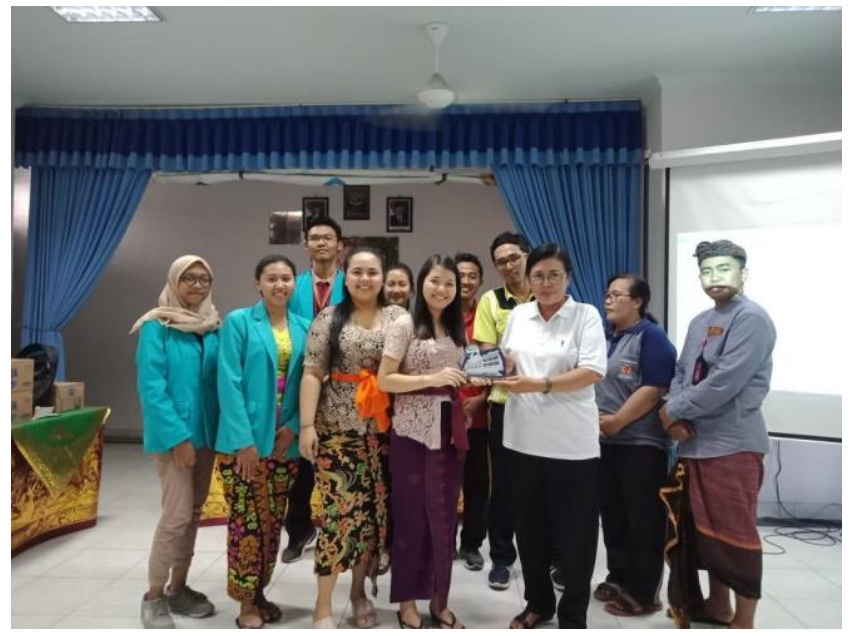

Gambar 3. Tim Pelaksana beserta pihak SD Negeri 2 Tibubeneng

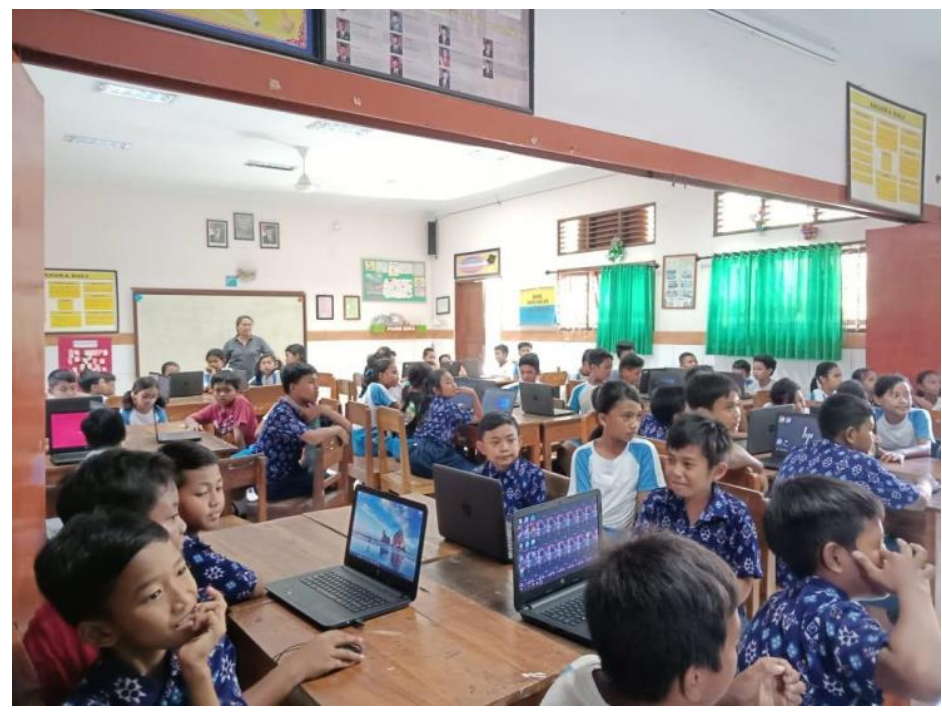

Gambar 4. Siswa Mendengarkan Materi Pelatihan 


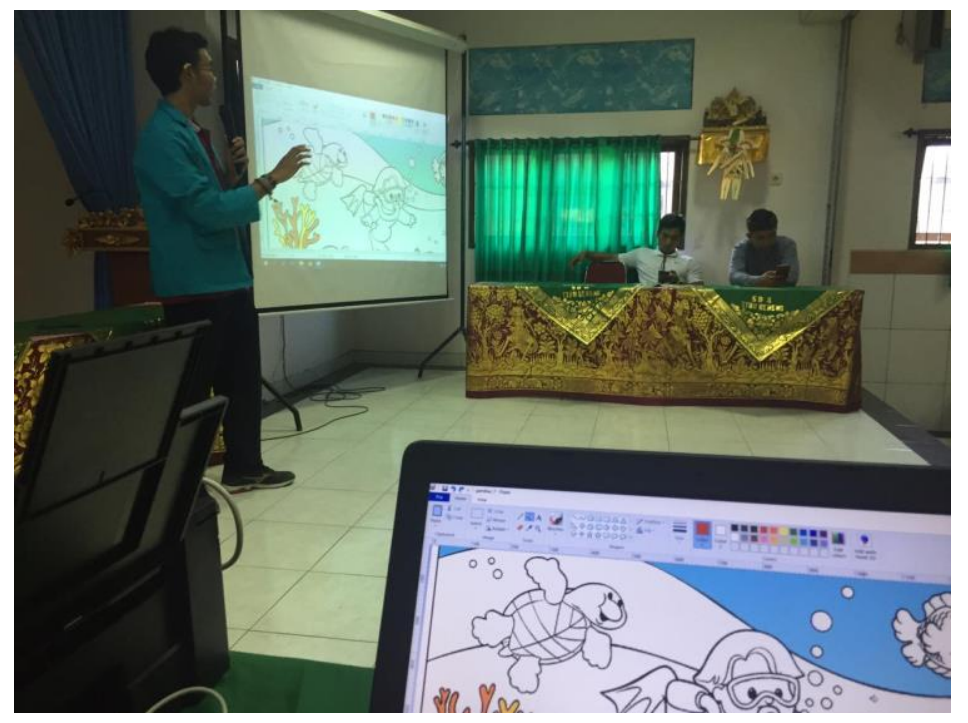

Gambar 5. Pelatihan Mewarnai dengan Aplikasi Paint

Pelatihan ini memberikan manfaat kepada siswa-siswi yakni sebagai bekal kepada siswa tentang keterampilan dasar komputer dan teknologi informasi khususnya internet bagi pengembangan ilmu pengetahuan, serta sebagai bentuk pengembangan nilai-nilai karakter dalam bidang pendidikan berupa rasa keingintahuan, kreatif, inovatif, dan komunikatif.

Hambatan yang di temukan beberapa praktik yang dilaksanakan kurang produktif, hal ini dikarenakan jumlah prasarana yang belum memadai sehingga memerlukan waktu yang lebih lama untuk melaksanakan pelatihan dan koneksi internet yang kurang stabil.

\section{SIMPULAN}

Pelaksanaan kegiatan pelatihan keterampilan dasar komputer dan teknologi informasi sudah terlaksana dengan baik. Siswa mampu memahami aplikasi dasar komputer dan penggunaan internet sehat. Tanggapan siswa terhadap pelaksanaan kegiatan ini sangat baik, dimana hal ini dapat dilihat dari indikator kehadiran siswa mencapai 100\% dari target,

http://ejournal.urindo.ac.id/index.php/PAMAS 
dan selama kegiatan berlangsung siswa sangat antusias mengikuti kegiatan dari awal sampai akhir kegiatan. Kegiatan ini juga mendapat respon yang positif oleh pihak SD Negeri 2 Tibubeneng, dimana hal tersebut dapat ditindaklanjuti dengan mengadakan berbagai pelatihan di bidang teknologi informasi lainnya.

\section{DAFTAR PUSTAKA}

Budiman, H. 2017. Peran Teknologi Informasi dan Komunikasi dalam Pendidikan. Jurnal Pendidikan, Vol. 8, No. 1, Universitas Islam Negeri Raden Intan Lampung.

Hayati, T, dkk. 2018. Meningkatkan Kemampuan Kecerdasan Visual melalui Aplikasi Paint. Jurnal Obsesi:Jurnal Pendidikan Anak Usia Dini, Vol. 2, No 1, IKIP Siliwangi Bandung.

Pemerintah Kab. Badung. 2015. Profil Wilayah Desa Tibubeneng. Tersedia:http://desatibubeneng.badungkab.go.id (diakses pada 12 September 2019)

Rokhman, M.M, dkk. 2018. Pelatihan Pemanfaatan Microsoft Office Pada Staf Pengajar di SMPLBN (Sekolah Menengah Pertama Luar Biasa Negeri) Kota Malang. Jurnal MNEMONIC, Vol. 1, No. 1, Institut Teknologi Nasional Malang.

Wikipedia. 2015. Tibubeneng. Tersedia: https://ms.wikipedia.org/wiki/Tibubeneng (diakses pada 12 September 2019) 